\title{
Credit Card in Albania
}

\author{
Agerti Galo \\ Lector in University "Ismail Qemali", Department of Finance \\ PhD candidate at Tirana University Finance Department
}

\section{Doi:10.5901/ajis.2016.v5n3s1p345}

\begin{abstract}
We can say with full conviction that the evolution of computer science, use and opportunities that credit cards provide to us, has made them the most used tools in the world today. Use of credit cards is simplified to the maximum, but behind them lies a complicated system of gains that begin and end up with the use of credit cards. In this great system that works perfectly different actors are in the race to increase their profit. Albania had been part of this system too late. Electronic cards market in Albania is composed of contemporary systems of credit cards, the not well informed users and banks that do not have an approval model for applications. This one because they have not needed such a thing yet. Lack of approval models for applications, even if it does not seem to be an emergency, it is a handicap that must be crossed in order to prevent socioeconomic problems that may arise in the future.
\end{abstract}

Keywords: Credit Card, Bank

\section{Introduction}

The first ideas on the credit card and its use are provided by the writer Edward Bellamy in the book entitled "Looking Backward". Author of the book by character Julian West shows how training will be economic in the world in 2000 (Drury \& Charles W. Ferrier, 1984 p.3).

After the book of Edward Bellamy only in 1914 was issued for the first example of the credit card company "General Petroleum Corporation" scattered workers and its loyal customers with card, where through it they can buy its products (Drury \& Charles W. Ferrier, 1984 p.3).

Bank of America was one of the first banks that gave rise to electronic communication network for the operation of credit cards. The formation of the electronic network increased the number of customers (credit cards) as well as their actions. Bank of America was one of the first banks that created the network, latter splitting by its own and giving that to another firm (This new company that emerged in the market to keep the electronic network of credit cards of Bank of America was Visa).

In 1970, following the example of Bank of America a number of financial companies that were in the same market merged the capital to form a network ICA (Intern bank Card Association) today known as MasterCard. In the same way the 1958 American Express Company created the "American Express", while Sears and Roebuck \& Co. created "Discover Card" in 1986 (Phil Brit, 2008, p.1).

\section{Operation of the Credit Card System}

There are two sets of credit card systems used worldwide. The first group is a unitary system and second association system (Sujit Chakravoti, 2003, p.4.).

Unitary System is elementary closed system which is composed of two actors and more skewed by the seller, while we are dealing with the seller and his loyal customers. For sellers who are not big enough to optimize the part of the costs, is not possible to set up such a system of credit card.

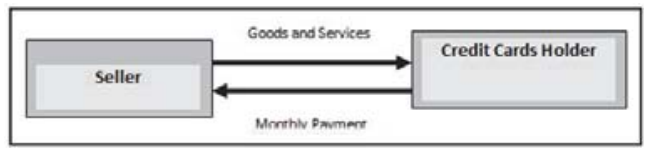

Scheme 1: Bilateral Model

Source: Federal Insurance Corporation 
Over time the amount of purchases grew and this brought the need for a third person to guarantee payments. In general, the third person was the bank. In this way with the development of technology, in addition to a closed system model, bilateral model emerged with three actors.

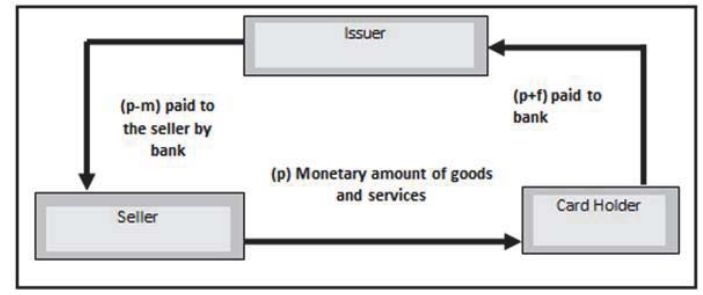

Scheme 2: Three Side Unitary System

Source: Lawrence J. White, 2006, s.16.

Company or the bank that issues credit card carries an important role at the unitary system. Bank or company that issued the credit card in such a situation is obliged to apply two sides Economics (Steve Semeraro, 2007, p 42).

In the unitary system the bank or company that issued the credit card should contact the consumers as well as retailers (Davit S. Evans, 2002, p.2). Nobody would like to have in possession a credit card which is not accepted by the sellers for making purchases or vice versa.

The scheme shows working of unitary system. If the vendor is selling goods or services with credit card to a customer in his account will not exceed the (p) value but a monetary value (p-m). The monetary amount value of $(m)$ held to retailers is called Merchant Discount Fee (Fumiko Hayashi, 2006, p.6). In this way credit card sales are six times higher than the cost in cash sales (Adam J. Levitin, 2007, p.1).

\section{Association System}

Banks and institutions that issue credit cards have a department that deals only with credit card customers and merchants that are equipped with POS machines. In order to reduce costs, this department began to be sold by banks or other institutions (Joshua S. Gans \& Stephen P. King, 2002, p.7). In this way we see the emergence of association system in the system the credit cards. In the association system of credit cards there are 4 economic elements but it is possible and there are times when we see even participate 5 economic elements. The 5 elements economic system is the most advanced and most complex.

\section{Four side credit card model of Association System}

Unlike the closed system, in four side system model is seen taking part company or intermediary banks too. The basic work of this company (Acquirer) is to contact sellers or merchants who want to use the POS machine, and enabling the use of credit card by achieving the agreement to use the POS machine (Ann Kjos, 2007. p.3). We find this type of system used in companies that issue credit cards like Visa and MasterCard (Chakravorti, 2003, p.54).

Credit card sales are a great advantage as they put away the problem of liquidity. Therefore sellers do all the duties assigned and create all the necessary conditions so that buyers use credit card (Robert A. Hendrickson, 1972, p.68).

For this reason the acquisition of the credit card holder is greater using the credit card as opposed to when he will be in cash buying goods and services (Hillel Black, 1961. p.30).

\section{Five side credit card model of Association System}

At the five side credit card model, the fifth element is network. Is not said that the firm which is offering network to be that one which is issuing credit cards. Meanwhile firms offering network at the same time can draw credit card.

Visa and MasterCard were the first firms that created and served network system to the market, after them Discovery came in the electronic payments market, too (Chakravorti, 2003, p.4). Almost all the world performs actions 
through this system created by these firms. If we are going to compare the system of Discovery with Visa and MasterCard, Visa and MasterCard system is superior in the market The Nilson Report, 2003. p.8).

This model is the top of the payment system by credit card, which already after an initial process hides a more complicated system in which some parties extend gains.

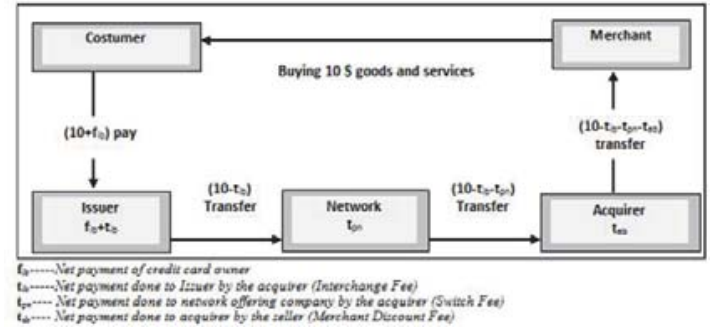

Scheme 4: Five Side Model Association System

Source: Lawrence J. White, 2006, p.17.

The five side model of association system is a very complicated system. This is clearly understandable by looking the way haw the transfer time is been establish. By studying this system we can understand that only one purchase created a profit of $(F I B)+(T I B)+(T P N)+($ tab). A question which has no answer regarding this gain is: that this is a profit that should be shared among the parties participating or payment of slavery is that modern society (Ralph Nader, 2003, p.3)?

\section{The system of credit card payments in Albania}

Electronic payments in the banking system of Albania have become part of banking market only after 2003. Despite the upward trend of the use of credit cards, Albanian banking market in the use of credit cards is far from markets of the region. This is one of the main reasons why the Albanian banking market does not have sophisticated systems for approving credit card applications.

The majority of commercial banks have left the approval of application for credit cards to simple bank employees in conditional on compliance with certain basic criteria, where the most important are income.

Statistical analysis of 240 applicants whom credit card had been approved and have used the latter since January 2015 showed that there is no meaningful link found between cause and those criteria due to consequences (late payment). Also had been attended another way to see if there is an approval model. Thus, each criterion that could affect the economic behavior of the applicant after he has received the credit card, it is estimated seeing average criteria consequence where in this case are the amount accumulative, credit card limit and the total costs to credit card.

\section{Statistical analysis}

At issue are received 240 applicants with an average of age 30 years of - 8.672 ALL for accumulative amount, 52.081 ALL to credit card limit and an average of spending to $92.288 \mathrm{ALL}$. In the group of applicants received regarding the size of the clusters in the relevant criteria for the criteria striking single social status group with about $86 \%$, for education criteria other group with $66.7 \%$ for the age group $20-30$ years criterion with $60.8 \%$ for employee grouping criterion personal profession with $21.3 \%$ and the amount of deposits grouping number 0 to $96.7 \%$.

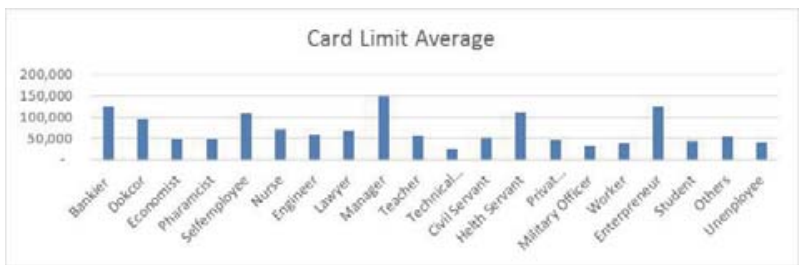

Figure 1: The average credit card limit by occupation

The largest grouping of expenses In groups of criteria "occupation" are doctors by an average of 417.448 ALL followed by 
bankers and managers respectively 247.680 and $213.741 \mathrm{ALL}$. While it is to be noted that the greater number of this group have "personal servant" followed by "labor" and "others", coupled with a limit of relatively low card. This contradiction shows that the bank has free hand to its employees that deal with the approval of the credit cards to use their intuition to approve or not the application to the last. This is a sign of the lack of target system based on statistical studies of approving credit card applications for this bank.

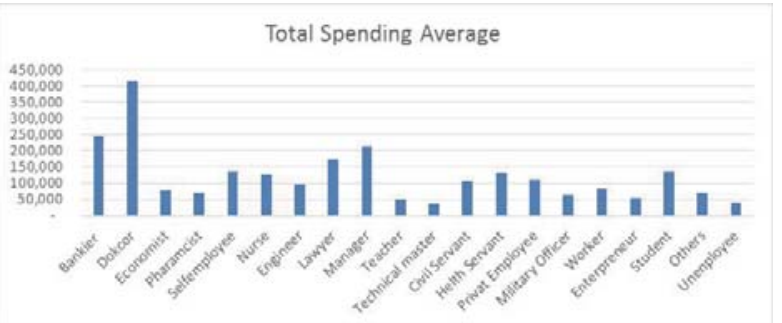

Figure 2: Average expenditure by occupation

Regarding the analysis of the approval of an application for a credit card from the bank it is seen that the group criteria, "occupation", the trustees of the bank are "personal servant" followed by "civil state". While professions that bank thinks will spend more and thus will bring the bank more profits are banker, doctor, self-employed, manager, health and entrepreneurial employees. Applicants who have exactly the professions within above, the bank has given credit card with a higher limit. Costs incurred by the latter show that this prediction of the bank cannot be called correct after applicants have had only profession banker, doctor and manager have had higher costs. Thus it can be said that banks in 6 professions which has offered the highest limit credit card 3 of them have fulfilled the purpose of giving a credit card with a high limit.

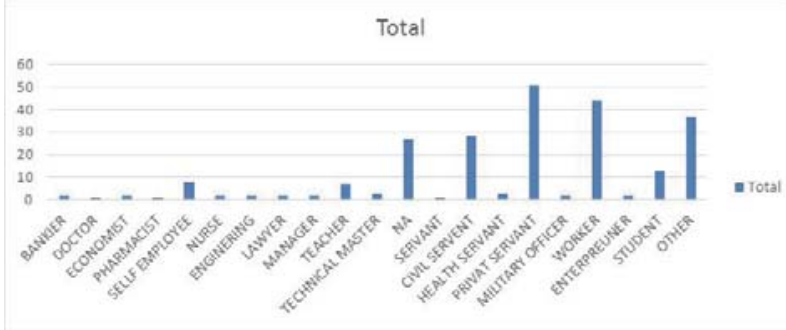

Figure 3: The amount of approvals for occupation

Regarding the costs of the biggest, if one will find the following diagram will discern easily that group who has fallen in the area of risk RG4, RG5, RG6 and RG2 has spent more than all other groups a fact which shows the bank has given approval for credit card taken in a prudent way. Conjugal relations that if we looked at how it spread limit credit cards in these groups we will see that greater limit have been groupings in RG5, RG6 and RG7 that shows that somehow the bank is not prudent in giving credit cards.

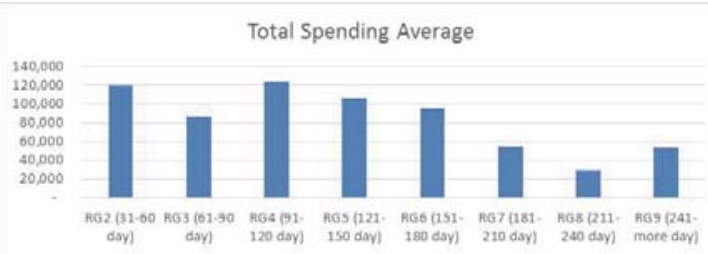

Figure 4: Total Spending by risk groups 


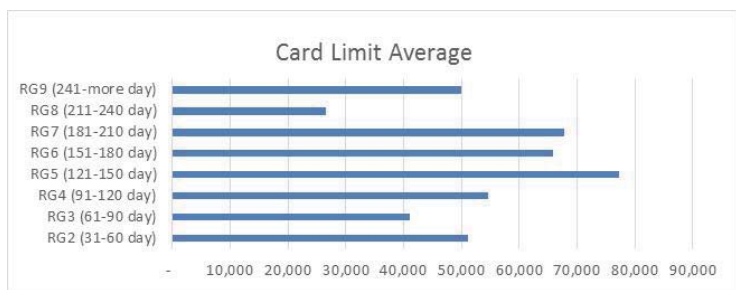

Figure 5: Card limit by risk groups

Both the above data are contradictory and confirm that credit cards officers (staff that has given credit cards to applicants), has had the subjective influences in addition to objective decision making. This connection is used to make credit card holders to pay their expenses for some time but that it subsequently not lasted. The reason is that at the outset that credit card data was a wrong decision. Precisely this makes the cost of the latter to be relatively high from the group even though they have fallen in the high-risk community.

\section{Conclusions and Discussions}

Seeing the growing trend of using credit cards in Albania is entirely foreseeable that in the coming years this mass use of credit cards will be a social and economic problem not only for the users but also the banks themselves. It saw that banks and financial institutions have emerged from their historic function to encourage savings and discourage debit directing customers away from savings and towards debit.

From observations on the data received from the commercial banks but also from annual reports of other banks it seems clear that delays in payment or not credit card payments are not yet a problem for banks.

Statistical analysis also highlights top again that banks do not have a model for approving credit card application on which to rely. Failure to have a profit model and affection arising from the issuance of credit cards will lead to large increase in credit card approvals. And finally in a long time not only an economic problem but also social nonpayment of debt borne by use of credit card.

While credit card system used in Albania by banks is the most advanced and complicated system of five side model. With the presence of such a system all stakeholders who take part in this system make all they best to get as much part of the profit from the use the credit card by the owner. The late introduction of the system of credit card payments in Albania and uninformed user makes this ones completely unprotected to these actors who will push to the limit for their profits. Precisely claim their winnings for these actors will be somehow of pushing towards a socialeconomic problem for all credit card users.

Measures should be taken to inform the users of credit cards over the risk by institutions that are not stakeholders of the payment system by credit card.

State shall issue regulation where it will determine possible minimums of the criteria for obtaining credit card.

State, before it is too late should establish an institution that deals with the monitoring of debt created by credit cards as the latter has a major social impact.

\section{References}

Tony Drury and Charles W. Ferrier, Credit Cards, Butterworths, London, 1984 p.3.

Phil Brit, "A Historical Overview of Bankcard Industry", Transaction World Magazine, Cover Story, p.1 (http://www.transactionworld.net /articles/2002/january/coverstory.asp) (12/05/2008)

Sujit Chakravoti. "Theory of Credit Card Networks: A Survey of the Literature", Federal Reserve Bank of Chicago, Review of Networks Economics, Vol.2, Issue 2, Chicago, June 2003,p.4.

Steve Semeraro, "Credit Card Interchange Fee: Three Decades of Antitrust Uncertainty", Legal studies Research Paper Series, March 6, 2007, p 42.

Davit S. Evans, "The Antitrust Economics of Two-Sided Markets", AEI-Brookings Joint Center for Regulatory Studies, Related Publication 02-13, September 2002, p.2.

Fumiko Hayashi, "Network Competion and Merchant Discount Fees", Payment System Research Department, Federal Reserve Bank of Kansas City, Working Paper (05-04), March 24, 2006, p.6.http://www.kansascityfed.org/publicat/psr/rwp/Hayashi_WP05_Network Competition\&MDF.pdf, (10/03/2008). 
Adam J. Levitin, "Priceless?The Cost of Credit Cards", Business, Economics and Regulatory Policy Working Paper Series, Georgetown University Law Center,Research paper No. 973974, September 2007, p.1.http://ssrn.com/abstract=1011106, (12/04/2008).

Joshua S. Gans and Stephen P. King "A Theoritical Analysis of Credit Card Regulation" Melbourne Business School, University of Melbourne, September 2002, p.7.

Ann Kjos, "The Merchant-Acquiring Side of the Payment Card Industry: Structure, Operations, and Challenges". Federal Reserve Bank of Philadelphia, Payment Cards Center Discussion Paper, October 2007. p.3. http://www.philadelphiafed.org/pcc/papers /2007/D2007OctoberMerchantAcquiring.pdf, (11/03/2008).

Robert A. Hendrickson, The cashless Society, Dodd Mead and Conpany, New York, 1972, p.68.

Hillel Black, Buy now, pay later, William Morrow and Company, New York, 1961. p,30.

"Credit and Debid Cards, Purchase Volume", The Nilson Report, Issue 797, October 2003. p.8.

Ralph Nader, "Plastic Money's Predatory Lenders", In the Public Interest, July 3, 2003. 